DOI: $10.19195 / 0137-1134.116 .9$

\author{
ADAM WRÓBEL \\ ORCID: 0000-0002-9315-0213 \\ Uniwersytet Humanistyczno-Przyrodniczy im. Jana Długosza w Częstochowie
}

\title{
GLOSA DO POSTANOWIENIA SN Z 30 MAJA 2017 ROKU, IV KK 164/17*
}

\begin{abstract}
Abstrakt: Sąd Najwyższy w postanowieniu z 30 maja 2017 roku, IV KK 164/17, będącym przedmiotem glosowania, wskazuje, że ,przestępstwa stypizowane w art. $160 \S 1-3$ k.k. mają charakter skutkowy (materialny) i należą do kategorii przestępstw z konkretnego narażenia na niebezpieczeństwo". Odnosi się w kontekście art. 160 k.k. między innymi do kwestii: niebezpieczeństwa o charakterze bezpośrednim, związku przyczynowego, formy czynu. W obszarze tej problematyki porusza się również autor glosy, przywołując oraz analizując poglądy wyrażane w doktrynie oraz orzecznictwie. Opierając się na poglądzie wyrażonym przez A. Spotowskiego podnosi, że bezpośredniość niebezpieczeństwa opiera się na czterech kryteriach, elementach (elemencie czasowym, elemencie stopnia prawdopodobieństwa, elemencie wystarczającej przyczyny czy elemencie nieuchronności), które przy określeniu bezpośredniości — zależnie od konkretnie zaistniałej sytuacji, okoliczności — łączy się lub stosuje alternatywnie. Toteż w kontekście określonej sytuacji można zaakceptować twierdzenie wyrażone przez SN, że „bezpośredniość niebezpieczeństwa należy wiązać nie tyle z bliskością czasową skutku mogącego nastąpić w związku z rozwojem sytuacji, ile ze stanem, gdy nieuchronnym następstwem dalszego rozwoju sytuacji, bez konieczności pojawienia się jakichś nowych czynników »dynamizujących «, jest niebezpieczeństwo dla życia lub zdrowia". Autor podziela pogląd SN, że odpowiedzialność sprawcy przestępstwa nieumyślnego wymaga nad stwierdzenie tego, że sprawca zachował się nieostrożnie, również iż sprawca „był świadomy tego, że swoim zachowaniem może zrealizować znamiona czynu zabronionego (przewidywał taką możliwość), bądź też, możliwości takiej nie przewidywał, chociaż mógł ją przewidzieć”. Autor wskazuje, że przestępstwo z art. $160 \S 1$ k.k. może zostać popełnione przez działanie albo zaniechanie, toteż odrzuca pogląd, że przestępstwo to może być popełnione wyłącznie w formie działania.
\end{abstract}

Słowa kluczowe: przestępstwo, narażenie człowieka na niebezpieczeństwo (art. 160 kodeksu karnego), bezpośrednie niebezpieczeństwo (utraty życia albo ciężkiego uszczerbku na zdrowiu)

W tezie glosowanego postanowienia Sądu Najwyższego wskazuje się, że „W art. 160 § 3 k.k. spenalizowano odmiany nieumyślne dwóch przestępstw umyślnych narażenia życia albo zdrowia człowieka na ciężki uszczerbek, ujętych w art. 160

* LEX nr 2321893. 
$\S 1$ k.k. oraz w art. $160 \S 2$ k.k. Nieumyślna strona podmiotowa tych przestępstw jest powodem ich uprzywilejowania, jako że brak zamiaru narażenia życia albo zdrowia człowieka na bezpośrednie niebezpieczeństwo utraty tych dóbr, znacznie obniża przede wszystkim stopień winy sprawcy, a oprócz tego także stopień społecznej szkodliwości popełnionego czynu. Odpowiedzialność za odmiany nieumyślne z art. 160 § 3 k.k. wchodzi w grę, gdy sprawcy można zarzucić świadome lub nieświadome naruszenie reguł ostrożności w postępowaniu z tymi najcenniejszymi dobrami człowieka w danych okolicznościach, w jakich miało to miejsce".

Sąd Najwyższy w glosowanym judykacie podnosi między innymi kwestie związane z przestępstwem narażenia człowieka na niebezpieczeństwo, określonym $w$ art. 160 k.k.; w tym odnosi się do zagadnień związanych $\mathrm{z}$ bezpośrednim niebezpieczeństwem, związkiem przyczynowym, formą czynu. Również glosujący koncentruje się na tychże zagadnieniach, starając się wskazywać, analizować poglądy wyrażane w orzecznictwie oraz literaturze przedmiotu.

Sąd Najwyższy zauważa, że ,przestępstwa stypizowane w art. 160 § 1-3 k.k. mają charakter skutkowy (materialny) i należą do kategorii przestępstw z konkretnego narażenia na niebezpieczeństwo. Do ich znamion należy skutek w postaci niebezpieczeństwa dla życia i zdrowia"; a konkretnie skutek w postaci narażenia człowieka na bezpośrednie niebezpieczeństwo utraty życia albo ciężkiego uszczerbku na zdrowiu. Można uzupełnić tę słuszną myśl, dookreślając, że utrata życia, śmierć, wiąże się z nieodwracalnym, trwałym ustaniem czynności całego mózgu, ergo nieodwracalnym, trwałym ustaniem jakiejkolwiek, wszelkiej czynności mózgu. Ciężki zaś uszczerbek na zdrowiu przyjmuje postać: pozbawienia człowieka wzroku, słuchu, mowy, zdolności płodzenia (156 § 1 pkt 1 k.k.), innego ciężkiego kalectwa, ciężkiej choroby nieuleczalnej lub długotrwałej, choroby realnie zagrażającej życiu, trwałej choroby psychicznej, całkowitej albo znacznej trwałej niezdolności do pracy w zawodzie lub trwałego, istotnego zeszpecenia lub zniekształcenia ciała (156 § 1 pkt 2 k.k.).

Sąd Najwyższy wyraża pogląd, że niebezpieczeństwo dla życia i zdrowia

oznacza sytuację - pewien szczególny układ rzeczy lub zjawisk odrębny od samego czynu, charakteryzujący się dynamicznym rozwojem - która ma właściwość przechodzenia w inny stan, natomiast bezpośredniość niebezpieczeństwa należy wiązać nie tyle z bliskością czasową skutku mogącego nastąpić w związku z rozwojem sytuacji, ile ze stanem, gdy nieuchronnym następstwem dalszego rozwoju sytuacji, bez konieczności pojawienia się jakichś nowych czynników „,dynamizujących", jest niebezpieczeństwo dla życia lub zdrowia ${ }^{1}$.

Sąd kontynuuje swój wywód, wskazując że „,skutkiem takiego działania sprawcy ma być sprowadzenie określonego stanu rzeczy, który charakteryzuje się tym,

1 Zob. jak podaje Sąd Najwyższy - A. Zoll, Kodeks karny. Część szczególna. Komentarz, t. 2, Warszawa 2008, s. 349-350. 
że towarzyszy mu pewien obiektywnie istniejący potencjał niebezpieczeństwa utraty życia albo ciężkiego uszczerbku na zdrowiu”. W cytowanym wywodzie Sąd Najwyższy porusza kwestię „,bezpośredniego niebezpieczeństwa” i związanego z nim następstwa. W orzecznictwie wskazuje się odnośnie do pojęcia bezpośredniego niebezpieczeństwa, że: grozi ono realnym nastąpieniem skutku, a „bezpośredniość realnie grożącego niebezpieczeństwa oznacza, iż w sytuacji przez sprawcę już stworzonej, a więc bez dalszej akcji z jego strony, istnieje znaczne prawdopodobieństwo nastąpienia w najbliższej chwili wymienionych skutków"2; należy je rozumieć „,bądź jako nieuchronne następstwo dalszego niebezpiecznego dla życia lub zdrowia rozwoju sytuacji, bądź jako wysokie prawdopodobieństwo jego wystąpienia"3; jego następstwo musi się charakteryzować „,wysokim prawdopodobieństwem spełnienia"4; jest „natychmiastowe, realne, konkretnie istniejące w sytuacji już stworzonej przez sprawcę bez jego dalszych możliwych działań"5. W perspektywie tychże poglądów wyrażanych w sądownictwie, niebezpieczeństwo bezpośrednie jawi się jako:

1. niebezpieczeństwo wysokiego prawdopodobieństwa wystąpienia powiązanego z nim następstwa,

2. niebezpieczeństwo pozbawione ogniw pośrednich w stosunku do powiązanego z nim następstwa,

3. niebezpieczeństwo natychmiastowe, realne, konkretne.

W glosowanym orzeczeniu wskazuje się na nieuchronność wystąpienia związanego z nim następstwa oraz niejako na wtórność bliskości czasowej między niebezpieczeństwem a jego następstwem ,bez konieczności pojawienia się jakichś nowych czynników »dynamizujących«". W określonym stanie rzeczy poglądy te można uznać za słuszne, niemniej ze względu na istotę bezpośredniego niebezpieczeństwa, należy odnosić się do nich w sposób elastyczny i podzielić w pełni konkluzję Andrzeja Spotowskiego, że

w doktrynie i orzecznictwie spotkać można różne sposoby określania bezpośredniości niebezpieczeństwa i różne ujęcia kryteriów bezpośredniości. Ogólnie rzecz biorąc, można wyodrębnić cztery ujęcia kryteriów bezpośredniości, a mianowicie opierające się na: — elemencie czasowym, — elemencie stopnia prawdopodobieństwa, - elemencie wystarczającej przyczyny, - elemencie nieuchronności. Niekiedy łączy się niektóre z podanych elementów bądź stosuje się je alternatywnie przy określaniu bezpośredniości ${ }^{6}$.

2 Teza do wyroku SN z 29 listopada 1973 roku, Rw 902/73, LEX nr 16804.

3 Postanowienie SN z 26 stycznia 2016 roku, V KK 342/15, LEX nr 1977834.

4 Postanowienie SN z 24 listopada 2009 roku, II KK 39/09, LEX nr 558347.

5 Teza do wyroku SA w Krakowie z 4 października 2007 roku, II AKa 132/07, LEX nr 365629. Zob. odnośnie do zagadnienia bezpośredniości niebezpieczeństwa A. Wróbel, Bezpośrednie niebezpieczeństwo jako element czynu zabronionego, „Zeszyty Prawnicze” 2014, nr 4, s. 189-198.

${ }^{6}$ A. Spotowski, Funkcja niebezpieczeństwa w prawie karnym, Warszawa 1990, s. 82. 
Każda sytuacja faktyczna, każdy przypadek poddawany analizie wymaga w perspektywie zbadania, czy zachodzi „bezpośrednie niebezpieczeństwo”, odniesienia się do konkretnych, zaistniałych okoliczności ${ }^{7}$.

W glosowanym judykacie Sąd Najwyższy podzielił pogląd wyrażony w postanowieniu (a właściwie w jego tezie) Sądu Najwyższego z 24 listopada 2009 roku, II KK 39/09, głoszący że

„aby przyjąć, że sprawca dokonał przestępstwa określonego w art. 160 § 3 k.k., konieczne jest ustalenie wystąpienia skutku w postaci bezpośredniego niebezpieczeństwa utraty życia albo ciężkiego uszczerbku na zdrowiu, co oznacza, że skutek ten musi charakteryzować się wysokim stopniem prawdopodobieństwa spełnienia, naraża go jednak w wyniku niezachowania wymaganej w danych okolicznościach ostrożności, w sytuacji, w której narażenie człowieka przewidywał lub obiektywnie biorąc mógł przewidzieć. Pod pojęciem przeciętnej ostrożności rozumieć trzeba ostrożność, której można wymagać od sprawcy na podstawie normalnej, dającej się przewidzieć, zdolności przewidywania skutków własnego czynu. Dla przypisania sprawcy odpowiedzialności za przestępstwo nieumyślne nie wystarczy jednak samo stwierdzenie, że zachował się on nieostrożnie, konieczne jest bowiem wykazanie, iż był świadomy tego, że swoim zachowaniem może zrealizować znamiona czynu zabronionego (przewidywał taką możliwość), bądź też możliwości takiej nie przewidywał, choć mógł ją przewidzieć (art. 9 § 2 k.k.). Możliwość przypisania sprawcy skutków czynu obejmuje jedynie normalne, a niewykraczające poza możliwość przewidywania, następstwa jego zachowania. I co równie ważne, następstwa te muszą pozostawać w związku z zawinionym naruszeniem tych reguł ostrożności, które w konkretnym układzie sytuacyjnym wywołało stan niebezpieczeństwa dla określonego dobra prawnego". Przenosząc powyższe rozważania na grunt niniejszej sprawy należy stwierdzić, że aby oskarżony mógł zostać uznany za sprawcę narażenia, to po pierwsze, jego zachowanie musiałoby naruszać wynikające $\mathrm{z}$ wiedzy i doświadczenia reguły postępowania $\mathrm{z}$ takimi dobrami jak życie i zdrowie, stwarzając niedające się zaakceptować prawdopodobieństwo ich naruszenia. Po drugie, do przypisania oskarżonemu D.G. odpowiedzialności w niniejszym postępowaniu konieczne było także stwierdzenie występowania kauzalnego powiązania między podejmowanym przez niego zachowaniem (naprawą opony), a skutkiem w postaci wywołania stanu narażenia.

W perspektywie tej należy podnieść, że ustawodawca przewidział w art. 160 $\S 3$ k.k. nieumyślną formę przestępstwa narażenia człowieka na niebezpieczeństwo. Definicja nieumyślności popełnienia czynu zabronionego znajduje się w art. 9 $\S 2$ k.k., który to przepis stanowi, że czyn zabroniony popełniony jest nieumyślnie, jeżeli sprawca, nie mając zamiaru jego popełnienia, popełnia go jednak na skutek niezachowania ostrożności wymaganej w danych okolicznościach, mimo że możliwość popełnienia tego czynu przewidywał (świadoma nieumyślność) albo mógł przewidzieć (nieświadoma nieumyślność) ${ }^{8}$. Ustawodawca wskazuje na „niezachowanie ostrożności wymaganej w danych okolicznościach”, toteż w orzecznictwie słusznie zauważa się, że

7 Por. postanowienie SN z 26 stycznia 2016 roku, V KK 342/15. Por. także A. Wróbel, Glosa do wyroku Sądu Najwyższego z 5 kwietnia 2013 r., IV KK 43/13, „Palestra” 2015, nr 3-4, s. 137-139.

${ }^{8}$ Pod. A. Zoll, [w:] Kodeks karny. Część ogólna, t. 1, cz. 1. Komentarz do art. 1-52, red. W. Wróbel, A. Zoll, Warszawa 2016, komentarz do art. 9, teza 33, https://sip.lex.pl/\#/commentary/587276762/510473 (dostęp: 19.03.2019). 
nie każde naruszenie reguł ostrożności pozwala na przypisanie sprawcy tego naruszenia popełnienia czynu zabronionego. Możliwość przypisania sprawcy skutków czynu obejmuje jedynie normalne, a nie wykraczające poza możliwość przewidywania, następstwa jego zachowania. I co równie ważne następstwa te muszą pozostawać w związku z zawinionym naruszeniem tych reguł ostrożności, które w konkretnym układzie sytuacyjnym wywołało stan niebezpieczeństwa dla określonego dobra prawnego?

Podobnie „dla prawidłowego ustalenia nieumyślności nie wystarczy wskazanie ogólnej nieostrożności zachowania sprawcy. Konieczne jest bowiem wskazanie konkretnej reguły ostrożności, która została naruszona, w wyniku czego doszło do popełnienia czynu zabronionego"10. Reguły ostrożności, jak podaje się w Uzasadnieniu projektu kodeksu karnego oraz w judykaturze,

są wypracowane, w zależności od rodzaju ludzkiej aktywności, odnośnie do określonych dóbr prawnych i dotyczyć mogą kwalifikacji działającej osoby, użytego w działaniu narzędzia lub sposobu realizowania zamierzonej czynności. Reguły te są dostosowane do warunków, w których określona czynność ma być podjęta. Nie przekreśla to możliwości ustalenia naruszenia ostrożności przez stworzenie takich warunków, w których dokonanie danej czynności jest dla chronionego dobra niebezpieczne ${ }^{11}$.

W związku z tym należy podzielić w przeważającej mierze — w sensie teoretycznym - pogląd wyrażony w glosowanym postanowieniu, głoszący że

dla przypisania sprawcy odpowiedzialności za przestępstwo nieumyślne nie wystarczy bowiem samo stwierdzenie, że zachował się on nieostrożnie, konieczne jest wykazanie, iż był świadomy tego, że swoim zachowaniem może zrealizować znamiona czynu zabronionego (przewidywał taką możliwość), bądź też, możliwości takiej nie przewidywał, chociaż mógł ją przewidzieć (art. 9 § 2 k.k.). Skutek taki — z punktu widzenia zachowania określonych reguł ostrożności przez sprawcę - musiałby charakteryzować się wysokim stopniem prawdopodobieństwa spełnienia. Sprawca bowiem, naruszając reguły, musiałby narażenie człowieka przewidywać lub obiektywnie biorąc, powinien móc je przewidzieć. Tymczasem na podstawie zebranego w sprawie materiału dowodowego, oskarżonemu nie można było przypisać skutków czynu w postaci wywołania stanu zagrożenia dla dobra prawnego, skoro zdolność przewidywania obejmuje jedynie normalne, a nie wykraczające poza możliwość przewidywania, następstwa jego zachowania. I co równie ważne, następstwa te muszą pozostawać w związku z zawinionym naruszeniem tych reguł ostrożności, które w konkretnym układzie sytuacyjnym wywołało stan niebezpieczeństwa dla określonego dobra prawnego.

Niejasna wydaje się jednak myśl, że skutek musiałby charakteryzować się „wysokim stopniem prawdopodobieństwem spełnienia”. Należałoby w tym przypadku doprecyzować, że chodzi nie o wysokie prawdopodobieństwo spełnienia

9 Wyrok Sądu Najwyższego z dnia 2 sierpnia 2001 roku, II KKN 63/99, LEX nr 51381.

10 Postanowienie SN z 5 listopada 2014 roku, V KK 162/14, LEX nr 1573978.

11 Uzasadnienie projektu kodeksu karnego, s. 121, cyt. za: M. Kulik, A. Wąsek, [w:] Kodeks karny. Komentarz, red. M. Filar, Warszawa 2016, komentarz do art. 9, teza 9; oraz wyrok SA w Warszawie z 8 marca 2017 r., II AKa 361/16, LEX nr 2278156; wyrok SA w Warszawie z 24 marca 2017 r., II AKa 109/16, LEX nr 2279522, https://sip.lex.pl/\#/commentary/587610963/503194 (dostęp: 14.03.2019). 
skutku z art. 160 § 1 k.k., mającego postać narażenia człowieka na bezpośrednie niebezpieczeństwo utraty życia albo ciężkiego uszczerbku na zdrowiu - co byłoby twierdzeniem błędnym - lecz o wysokie prawdopodobieństwo następstw narażenia człowieka na bezpośrednie niebezpieczeństwo utraty życia albo ciężkiego uszczerbku na zdrowiu, czyli faktycznego pozbawienia życia lub ciężkiego uszczerbku na zdrowiu ${ }^{12}$.

Sąd Najwyższy podnosi w glosowanym orzeczeniu, kontynuując swe rozważania dotyczące zrealizowania czynu zabronionego w formie działania albo zaniechania i związku przyczynowego pomiędzy tymiż a przestępnym skutkiem ${ }^{13}$, że

co więcej, w doktrynie słusznie przyjęto koncepcję, zgodnie z którą przestępstwo określone $\mathrm{w}$ art. $160 \S 1$ k.k. może być popełnione tylko przez działanie. Zaniechanie jest podstawą odpowiedzialności za sprowadzenie bezpośredniego niebezpieczeństwa tylko wtedy, gdy na sprawcy ciążył prawny, szczególny obowiązek zapobiegnięcia narażeniu na niebezpieczeństwo, czyli, gdy są zrealizowane od strony podmiotu czynu zabronionego, znamiona typu określonego w art. $160 \S 2$ k.k. (por. Kodeks karny. Część szczególna. Komentarz. Tom II, pod red. A. Zolla, Warszawa 2008, s. 348). Zaś taka sytuacja nie zachodziła w niniejszej sprawie. Skoro bowiem w $\S 3$ tego przepisu penalizowane jest zachowanie polegające na wypełnieniu znamion art. $160 \S 1$ k.k., jednak poprzez zachowanie nieumyślne, to również w tym przypadku musi w nim chodzić o przestępstwo $\mathrm{z}$ działania, a nie z zaniechania.

Z poglądem głoszącym, że czyn zabroniony określony w art. 160 § 1 k.k. może być popełniony jedynie przez działanie - wybrzmiewającym zarówno w dok-

12 Por. A. Wróbel, Glosa do wyroku Sądu Najwyższego z 5 kwietnia 2013..., s. 136; oraz A. Wróbel, Glosa do wyroku Sadu Apelacyjnego w Krakowie z dnia 7 września 2005 r., sygn. II AKa 165/05. Prok. i Pr. dodatek „Orzecznictwo” nr 4/2006, poz. 27, Orzecznictwo Sądów Apelacyjnych 2013, nr 4, s. 119-120.

13 Sąd Najwyższy wyraża co do tej materii pogląd, że „nie można zgodzić się z twierdzeniem obrońcy, iż »zaniechanie ze swojej natury jest nieprzyczynowe«, co miałoby prowadzić do wniosku, że między zaniechaniem a zarzuconym skutkiem nie należy badać istnienia związku przyczynowego, bo z natury rzeczy go tam nie ma. Co prawda, problem ten jest dyskusyjny w doktrynie, lecz nie znajdzie zastosowania w niniejszej sprawie, skoro oskarżonemu zarzucono działanie, a nie zaniechanie. Nawet zresztą gdyby przyjąć pogląd zaprezentowany przez autora kasacji — polegający na tym, iż zarzucany oskarżonemu czyn miał postać zaniechania — to należy wskazać, że przestępstwa z tzw. zaniechania również wymagają powiązania przyczynowego tegoż zaniechania ze skutkiem. Dla przyjęcia sprawstwa, oprócz potwierdzenia powiązania przyczynowego zaniechania ze skutkiem testem warunku sine qua non, niezbędne jest jednak przede wszystkim sprawdzenie, czy na sprawcy, który dopuścił się zaniechania, ciążył prawny szczególny obowiązek zapobiegnięcia skutkowi - a więc, czy był gwarantem nienastąpienia skutku. Jeśli skutek stanowiący ustawowe znamię przestępstwa popełnionego przez zaniechanie jest następstwem bezprawnych zachowań wielu osób, to zważywszy na treść art. 2 k.k., może być on przypisany tym tylko, które nie wykonały ciążącego na nich prawnego, szczególnego obowiązku zapobiegnięcia skutkowi i tylko wtedy, gdy w nastąpieniu skutku urzeczywistniło się niebezpieczeństwo, które wykonanie tego obowiązku miało odwrócić (por. wyrok SN z dnia 24 lutego 2005 r., V KK 375/04, OSNKW 2005, z. 3, poz. 31)". 
trynie $^{14}$, judykaturze ${ }^{15}$, jak i podzielanym przez Sąd Najwyższy w analizowanym postanowieniu — nie sposób się jednak zgodzić. Czyn zabroniony określony w art. $160 \S 1$ k.k. może być bowiem zrealizowany w dwóch formach: działania albo zaniechania ${ }^{16}$, na co zwraca się uwagę także w doktrynie ${ }^{17}$ i orzecznictwie $^{18}$. Na możliwość zrealizowania przestępstwa z art. $160 \S 1$ k.k. w formie zaniechania wskazują pośrednio chociażby przepisy:

1. art. 304 ustawy z 26 czerwca 1974 roku Kodeks pracy ${ }^{19}$, stanowiący wprost, że pracodawca jest obowiązany zapewnić bezpieczne i higieniczne warunki pracy, o których mowa w art. 207 § 2, osobom fizycznym wykonującym pracę na innej podstawie niż stosunek pracy w zakładzie pracy lub w miejscu wyznaczonym przez pracodawcę, a także osobom prowadzącym w zakładzie pracy lub w miejscu wyznaczonym przez pracodawcę na własny rachunek działalność gospodarczą $(\S 1)$; w razie prowadzenia prac w miejscu, do którego mają dostęp osoby niebiorące udziału w procesie pracy, pracodawca jest obowiązany zastosować środki niezbędne do zapewnienia ochrony życia i zdrowia tym osobom (§ 4);

2. art. 51 ustawy z 20 lipca 2018 roku Prawo o szkolnictwie wyższym i na$u_{c e}{ }^{20}$, określający między innymi, że na rektorze spoczywa obowiązek zapewnienia bezpiecznych i higienicznych warunków kształcenia w szczególności przez udostępnienie odpowiedniej infrastruktury oraz prowadzenie szkoleń. Naruszenie obowiązków wskazanych w wymienionych przepisach przez gwaranta (pracodawcę lub odpowiednio rektora), jeżeli prowadziłoby do narażenia człowieka na bezpośrednie niebezpieczeństwo utraty życia albo ciężkiego uszczerbku na zdrowiu, mogłoby wiązać się z popełnieniem przestępstwa z art. $160 § 1$ k.k. w formie zaniechania. Generalnie rzecz ujmując, sprawcą przestępstwa z art. $160 \S 1$ k.k. w perspektywie art. 2 k.k., może być gwarant, który przez swoje zaniechanie obowiązku spoczywającego na mim na mocy prawa - aktu normatywnego, orzeczenia sądu, umowy czy też jakiejś skonkretyzowanej sytuacji faktycznej, w której w sposób jednoznaczny urzeczywistnia się powstanie po stronie gwaranta wymagania

14 A. Zoll, [w:] Kodeks karny. Część szczególna, t. 2, cz. 1, Komentarz do art. 117-211a, red. W. Wróbel, A. Zoll, Warszawa 2017, komentarz do art. 160, teza 9, https://sip.lex.pl/\#/ commentary/587286899/543412J (dostęp: 18.03.2019); J. Giezek, [w:] Kodeks karny. Część szczególna. Komentarz, red. J. Giezek, LEX 2014, komentarz do art. 160, teza 7, https://sip.lex.pl/\#/commentary/587370853/168293 (dostęp: 18.03.2019).

15 Teza do wyroku SA w Łodzi z 9 marca 1995 roku, II AKr 40/95, LEX nr 24479.

16 Por. A. Wróbel, Glosa do wyroku Sądu Apelacyjnego w Krakowie z dnia 7 września 2005 r..., s. $114-119$.

17 V. Konarska-Wrzosek, [w:] Kodeks karny. Komentarz, red. V. Konarska-Wrzosek, Warszawa 2018, komentarz do art. 160, teza 4, https://sip.lex.pl/\#/commentary/587715802/571061 (dostęp: 18.03.2019); A. Marek, Kodeks karny. Komentarz, LEX 2010, komentarz do art. 160, teza 1, https:// sip.lex.pl/\#/commentary/587269705/59846 (dostęp: 18.03.2019).

18 Wyrok SN z 8 grudnia 2011 roku, II KK 177/11, LEX nr 1129045; teza do wyroku SA w Krakowie z 7 września 2005 roku, II AKa 162/05, LEX nr 164408.

19 Tekst jedn. Dz.U. z 2018 r. poz. 917 ze zm.

20 Dz.U. z 2018 r. poz. 1668 ze zm. 
zapobieżenia powstaniu skutku z art. $160 \S 1$ k.k. — naraża człowieka na bezpośrednie niebezpieczeństwo utraty życia albo ciężkiego uszczerbku na zdrowiu ${ }^{21}$.

Podnieść również należy, że jeżeli zrealizowany czyn zawierałby dodatkowe elementy, jak:

1. sprawca tegoż byłby pracodawcą, pokrzywdzony zaś pracownikiem,

2. na sprawcy ciążyłby obowiązek opieki nad pokrzywdzonym wówczas odpowiednio mogłoby dojść do popełnienia przestępstwa określonego w art. $220 \S 1$ k.k. (odnośnie do 1) albo 160 § 2 k.k. (odnośnie do 2).

Glosator wskazuje, że w określonym stanie rzeczy można zaaprobować twierdzenie, że w perspektywie art. $160 \S 1$ k.k. „bezpośredniość niebezpieczeństwa należy wiązać nie tyle z bliskością czasową skutku mogącego nastąpić w związku z rozwojem sytuacji, ile ze stanem, gdy nieuchronnym następstwem dalszego rozwoju sytuacji, bez konieczności pojawienia się jakichś nowych czynników »dynamizujących«, jest niebezpieczeństwo dla życia lub zdrowia”. Niemniej autor przytacza i podziela pogląd wyrażany w doktrynie, że „można wyodrębnić cztery ujęcia kryteriów bezpośredniości" (w perspektywie bezpośredniego niebezpieczeństwa), opierające się na elementach: czasowym, stopnia prawdopodobieństwa, wystarczającej przyczyny, nieuchronności; ,,niekiedy łączy się niektóre z podanych elementów bądź stosuje się je alternatywnie przy określaniu bezpośredniości”22. Każda osobna sytuacja wymaga bowiem w perspektywie zbadania, czy zachodzi „bezpośrednie niebezpieczeństwo”, odniesienia się do konkretnych, zaistniałych okoliczności. Glosujący uważa za słuszne twierdzenie, że

dla przypisania sprawcy odpowiedzialności za przestępstwo nieumyślne nie wystarczy bowiem samo stwierdzenie, że zachował się on nieostrożnie, konieczne jest wykazanie, iż był świadomy tego, że swoim zachowaniem może zrealizować znamiona czynu zabronionego (przewidywał taką możliwość), bądź też, możliwości takiej nie przewidywał, chociaż mógł ją przewidzieć.

Autor odrzuca pogląd wyrażony przez Sąd Najwyższy w judykacie będącym przedmiotem glosowania, że przestępstwo $\mathrm{z}$ art. 160 § 1 k.k. może być popełnione wyłącznie przez działanie, albowiem w perspektywie tego czynu, co udowadnia, możliwe jest zaistnienie dwóch form: działania albo zaniechania.

21 Zob. wyrok SN z 4 marca 2015 roku, IV KK 32/15, LEX nr 1650300.

22 A. Spotowski, Funkcja niebezpieczeństwa..., s. 82. 


\title{
COMMENTARY ON THE DECISION OF THE SUPREME COURT OF 30 MAY 2017, IV KK 164/17
}

\author{
Summary
}

The author indicates that it is possible - in a certain state of things - to approve the claim of Article $160 \S 1$ of the Criminal Code that the immediacy of danger should be associated not so much with the temporal proximity of the effect that may occur in relation to the development of the situation, as with the condition when the inevitable consequence of the further development of the situation (without the need for any new dynamizing factors) constitutes a risk to one's life or health. Nevertheless, the author cites and shares the view expressed in the doctrine that four views of criteria of directness can be distinguished (in the perspective of imminent danger), based on a time element, an element of probability, an element of sufficient cause, an element of inevitability; sometimes some of the given elements are combined or used alternatively in the determination of immediacy (A. Spotowski, Funkcja niebezpieczeństwa w prawie karnym, Warszawa 1990, p. 82). Each separate situation requires - in the perspective of examining whether there exists an "immediate danger" - reference to specific, existing circumstances. The author considers it right that in order to attribute the responsibility to the perpetrator for unintentional crime it is not enough to say that he had been careless. It is necessary to demonstrate that he was aware that his behavior can lead to the prohibited act (provided such a possibility), or, did not provide for such possibility, although it could have been provided. The author rejects the view that the crime specified in Article $160 \S 1$ of the Criminal Code can be committed only by action because in the perspective of this deed which he proves in the commentary - two forms may exist: action or omission.

Keywords: crime, exposure a human person to danger (Article 160 of Polish Criminal Code), immediate danger (of loss of life or serious damage of health)

\section{BIBLIOGRAFIA}

\section{AKTY PRAWNE}

Ustawa z 26 czerwca 1974 roku Kodeks pracy (tekst jedn. Dz.U. z 2018 r. poz. 917 ze zm.). Ustawa z 6 czerwca 1997 roku Kodeks karny (tekst jedn. Dz.U. z 2018 r. poz. 1600 ze zm.). Ustawa z 20 lipca 2018 roku Prawo o szkolnictwie wyższym i nauce (Dz.U. z 2018 r. poz. 1668 ze zm.).

\section{LITERATURA}

Kodeks karny. Część ogólna, t. 1, cz. 1. Komentarz do art. 1-52, red. W. Wróbel, A. Zoll, Warszawa 2016, LEX - System Informacji Prawnej (dostęp: 19.03.2019).

Kodeks karny. Część szczególna, t. 2, cz. 1. Komentarz do art. 117-211a, red. W. Wróbel, A. Zoll, Warszawa 2017, LEX — System Informacji Prawnej (dostęp: 18.03.2019).

Kodeks karny. Część szczególna. Komentarz, red. J. Giezek, Warszawa 2014, LEX — System Informacji Prawnej (dostęp: 18.03.2019).

Kodeks karny. Komentarz, red. M. Filar, Warszawa 2016, LEX — System Informacji Prawnej (dostęp: 14.03.2019).

Kodeks karny. Komentarz, red. V. Konarska-Wrzosek, Warszawa 2018 LEX — System Informacji Prawnej (dostęp: 18.03.2019). 
Marek A., Kodeks karny. Komentarz, Warszawa 2010, LEX — System Informacji Prawnej (dostęp: 18.03.2019).

Spotowski A., Funkcja niebezpieczeństwa w prawie karnym, Warszawa 1990.

Wróbel A., Bezpośrednie niebezpieczeństwo jako element czynu zabronionego, „Zeszyty Prawnicze" 2014, nr 4.

Wróbel A., Glosa do wyroku Sądu Apelacyjnego w Krakowie z dnia 7 września 2005 r., sygn. II AKa 165/05 (Prok. i Pr. dodatek „Orzecznictwo” nr 4/2006, poz. 27), Orzecznictwo Sądów Apelacyjnych 2013, nr 4.

Wróbel A., Glosa do wyroku Sądu Najwyższego z 5 kwietnia 2013 r., IV KK 43/13, „Palestra” 2015, nr 3-4.

Zoll A., Kodeks Karny. Część szczególna. Komentarz, t. 2, Warszawa 2008.

\section{ORZECZNICTWO}

Postanowienie SN z 24 listopada 2009 roku, II KK 39/09, LEX nr 558347.

Postanowienie SN z 5 listopada 2014 roku, V KK 162/14, LEX nr 1573978.

Postanowienie SN z 26 stycznia 2016 roku, V KK 342/15, LEX nr 1977834.

Wyrok SA w Łodzi z 9 marca 1995 roku, II AKr 40/95, LEX nr 24479.

Wyrok SA w Krakowie z 7 września 2005 roku, II AKa 162/05, LEX nr 164408.

Wyrok SA w Krakowie z 4 października 2007 roku, II AKa 132/07, LEX nr 365629.

Wyrok SA w Warszawie z 8 marca 2017 roku, II AKa 361/16, LEX nr 2278156.

Wyrok SA w Warszawie z 24 marca 2017 roku, II AKa 109/16, LEX nr 2279522.

Wyrok SN z 29 listopada 1973 roku, Rw 902/73, LEX nr 16804.

Wyrok SN z dnia 2 sierpnia 2001 roku, II KKN 63/99, LEX nr 51381.

Wyrok SN z 8 grudnia 2011 roku, II KK 177/11, LEX nr 1129045.

Wyrok SN z 4 marca 2015 roku, IV KK 32/15, LEX nr 1650300. 